\title{
TYPOLOGY OF WEB APPLICATIONS FOR LEARNING
}

\author{
Libor Klubal $^{1}$, Vojtěch Gybas ${ }^{2}$ and Kateřina Kostolányová ${ }^{3}$ \\ ${ }^{1} \mathrm{Mgr}$. \\ ${ }^{2} M g r$. Ph.D \\ 3Doc. Ing., Ph.D \\ University of Ostrava, Pedagogical Faculty, Department of Information and Communication Technologies \\ Fráni Šrámka 3, Ostrava, Mariánské Hory, 70900, Czech Republic
}

\begin{abstract}
Web applications represent an important group of applications that can be used in education. Usual division of web applications is based on their function. The article deals with the distribution of web applications according to the usual type of activity performed during the teaching. It introduces a new division of such a group of applications and lists the typical representatives of this applications.
\end{abstract}

\section{KEYWORDS}

Web Application, Web 2.0, Phases of Teaching

\section{INTRODUCTION}

The history of the Internet is generally known and for the purpose of this post, it is worth mentioning only the basic data regarding the services of the website. The very concept of the www pages appeared in 1989, and in 1991 CERN was fully utilized as a tool for spreading information from the author to the recipient. The first publicly accessible web browser appeared in 1993. Subsequently, up to the end of the 20th century, the number of connected users increased, reaching about 200 million in 1999. Still, at this time, we are talking only about a service that is primarily focused on disseminating information in one direction, usually from the author of the content (website) to the potential reader. Backward communication works only to a very limited extent. The actual creation of the pages is reserved for technically competent users.

In 1999, the Web 2.0 concept first appeared and is freely translated as follows:

"The Web we now know, which is only static in the browser window, is just the embryo of the site that appears, and the first Web 2.0 flashes are beginning to appear, and we can see how they are evolving. a lot of content with text and pictures, but as interactively-controlled transmission media, everything will be [...] displayed on the computer monitor, [...] on the television display, [...] on the car panel, [...] in your mobile phone, [...] on a game console, [...] and maybe even on a microwave. "(DiNucci, 1999). Another wave of widening the concept of Web 2.0 occurs in 2004 through a conference organized by Medialive in collaboration with well-known author Tim O'Reillym. This author also attempted to redefine the term and defined it as:

"Web 2.0 is a revolution in the computing industry, driven by a move to understanding the site as a platform and an attempt to understand the success story on this new platform." The key to these are: creating applications that are getting better with networking with an increasing number of users. Which I have called elsewhere "the attribution of collective intelligence." "(O'Reilly, 2005).

\section{TYPOLOGY OF WEB APPLICATIONS}

In the area of education, we can find a large number of web applications on the Internet, and their operation is often completely free of charge. The school does not have to pay for the license fees and the only cost remains to ensure a sufficient infrastructure. In the case of mobile touch devices, this is especially the requirement for a good wireless network. 


\subsection{Typology by Bower}

A very detailed typology of educational applications was conducted by Matt Bower in his study "Deriving and Typology of Web 2.0 Learning Technologies". In this study he analyzed over 200 web applications that are suitable for use in schools or for educational purposes. One reason for making such an analysis was, according to Bower, also a low rate of use of these tools in real-life practice. According to the available information (for example, from CSI conclusions), it can be said that the situation in Czech education is very similar. Even though teachers are offered a vast array of free tools that can help increase learning attractiveness, their use is not common. Mat Bower continually updates its typology, but for the basic orientation of existing services, we can use the first (and certainly still valid) version that divides the app into 14 categories as follows:
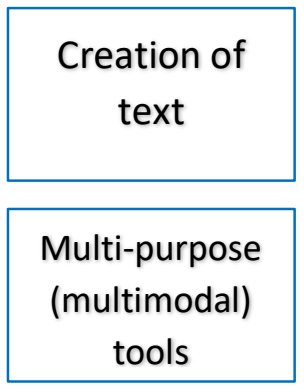

Work with the
data
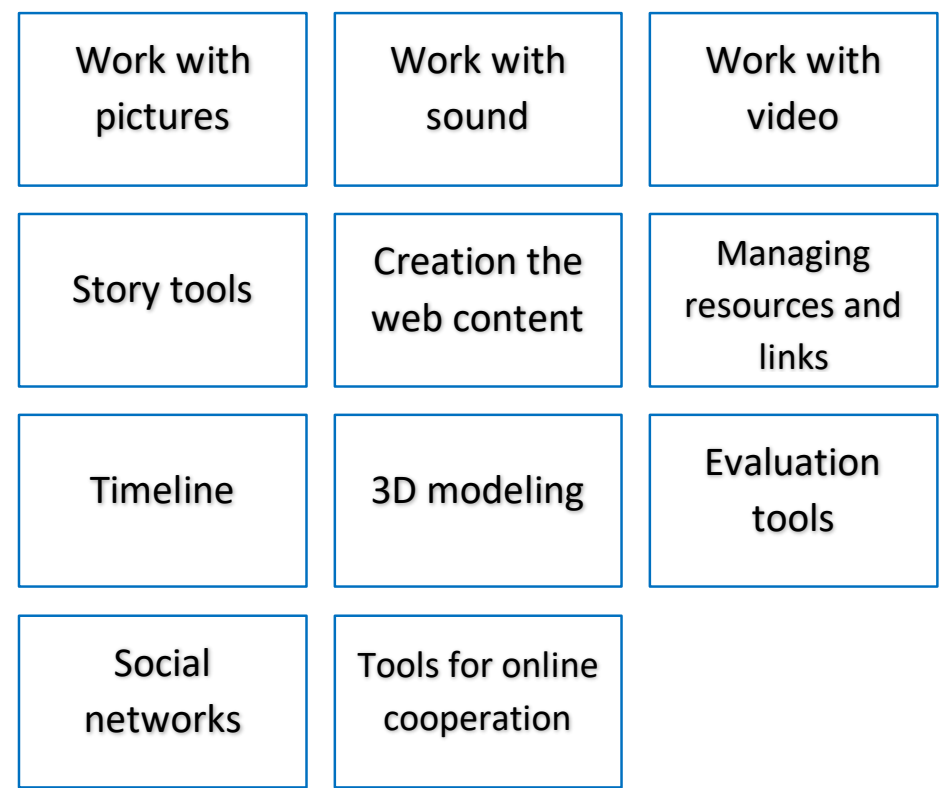

Figure 1. Types of web applications by Bower

\section{Tools for online cooperation}

Most categories are then subdivided into other subgroups and are currently in a total of 46 categories. However, it is quite difficult to include each particular application into one of the groups and often overlap.

\subsection{Typology by Activity}

The Bower typology is relatively broad in terms of practical use and therefore it would be more appropriate to introduce a typology based on the activities performed during the classroom for the purposes of classical schooling. We usually divide our own learning process into several phases. This is the motivation when a teacher and a teacher try to engage pupils in relation to content. The second phase is an exposure where new knowledge is passed on and the basis for skills and habits is created. The last phase is fixation, which helps to re-establish and consolidate knowledge and skills. The actual fixation methods are divided according to whether we fix knowledge or skills. In the framework of the teaching process, we use different forms of teaching (Průcha et al., 2013). Based on this division, we can categorize web apps as follows:

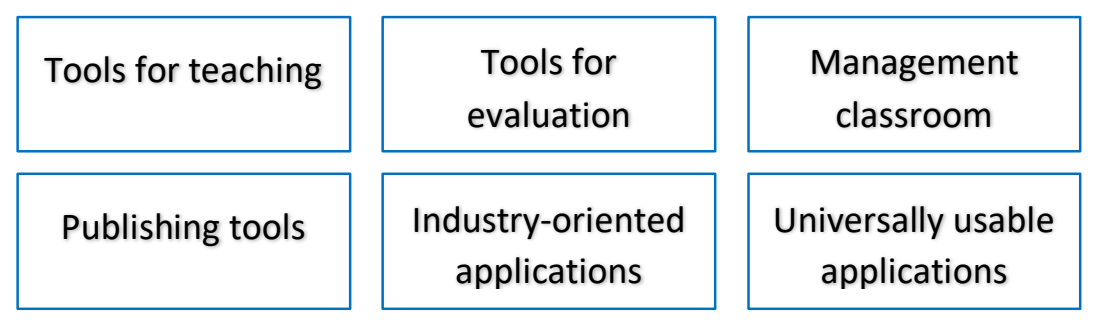

Figure 2. Typology of web applications by activity 


\subsection{Instruction for Teaching}

In the real practice of the school, the frontal style of teaching is still prevalent. This is apparent from regular reports from the Czech School Inspectorate, which show that the use of this method of education is increasing with the age of educated pupils. However, this is also a way of education at Czech schools, which is more focused on their own content than on learning strategies and competencies. Front-class teaching is a way of teaching, in which the teacher works in a collective way with all pupils in the class in one form and with the same content (Průcha et al., 2013). The disadvantages of such a method of teaching are obvious and are described in the literature - in particular, it is a small space for differentiation, enabling pupils' passivity and a low development of competences for learning. We can consider the benefits of saving time, clear, understandable and systematic submission of lessons or eliminating mistakes in interpretation. From the point of view of ICT, a typical presentation of a frontal education is a projected presentation accompanied by a teacher's interpretation. However, with the mass arrival of mobile devices, some of the disadvantages of the frontal learning can be eliminated. These include, in particular, the low passivity of pupils and the possibility of gaining instant feedback during the interpretation, and possibly influencing the content being further discussed. (Kostolányová, Klubal, 2015). Typical web application representatives in this category are Nearpod, which offers the ability to create interactive presentations with feedback tools. We can also use the "Classkick" application, which makes it possible to deal with the different working temps of individual pupils. The use of the above-mentioned applications is particularly motivational and exponential.

\subsection{Evaluation Tools}

An integral part of the teacher's work is student assessment. Student assessment has some form of communication about the extent of their success in the learning process. The issue of the various functions, forms and types of assessment is dealt with in the professional pedagogical literature and is not covered by this text. From a practical point of view, however, we need to address the complexity of the evaluation process for teachers and their facilitation through ICT tools. The evaluation app category is very extensive, and usually an evaluation module also includes tools from other categories. Web applications that focus exclusively on evaluation are Socrative, Kahoot! or Quizizz. These applications will be particularly useful in the fictitious phase within the proposed typology.

\subsection{School Class Management}

The actual process of teaching the lesson is quite demanding in view of the many different activities of the teacher. The teacher teaches students various forms of teaching materials (texts, links, presentations, pictorial material), records their study results, collects their work and evaluates them, ensures mutual communication, etc. For this type of activity, there are tools that we call collectively the tools for digital class management. Typical examples of such tools include Google Classroom, Edmodo, and Seesaw. These are quite complex tools and their overall description goes beyond the scope of this paper. Within the proposed typology, these applications are particularly suitable for exposure and fixation phases.

\subsection{Publishing Tools}

The ability to create web content has long been a difficult code writing and its subsequent transfer to the Internet using special protocols. With the advent of Web 2.0, website creation has become a relatively simple matter, and today it is an activity that can be compared with writing in a text editor. For teachers, the ability to create web content is a significant simplification of its routine activities. It is able to gradually create its own digital portfolio of learning materials that are subsequently available to pupils. In addition, pupils are used to receiving information in digital form. From the point of view of the proposed typology, these are mainly areas of exposure and motivation. 


\subsection{Branch-oriented Applications}

Industry-oriented applications find their place especially in the exposure and fixation phase. Providing a complete list of such applications is not possible within this post. That's why I'm just typing a representative for teaching foreign languages - Quizlet.

\subsection{Universally Applicable Applications}

No categorization can unambiguously divide web applications according to a particular purpose. Therefore, it would be a mistake to omit applications that can be used in all parts of the teaching process. An example of such applications may be Padlet for creating electronic tapes, or Diigo for managing links to electronic resources.

\section{CONCLUSION}

Web 2.0 does not mean changing the technologies used, but other ways of using, changing access to work with the Internet. From the point of view of content creation, it is no longer an activity reserved only for a narrow circle of technically savvy users. It begins to work with the concept of a web application that makes it possible to use the web bidirectionally. This short post attempts to introduce a categorization of web applications by activity performed during the course. In any case, this is not the only possible way, but it provides the opportunity to find suitable applications for what the teacher does in the classroom.

\section{REFERENCES}

Bergmann, Jonathan; SAMS, Aaron. Flip your classroom: Reach every student in every class every day. International Society for Technology in Education, 2012.

Bower, M., 2016. Deriving a typology of Web 2.0 learning technologies. British Journal of Educational Technology, 47(4), pp. 763-777.

Dinucci, D. (1999) Fragmented future. Print Magazine, 4, 32. Retrieved 3/12/17 from http://darcyd.com/fragmented_future.pdf

Edrees M.E. ELearning 2.0: Learning management systems readiness, Proceedings - 2013 4th International Conference on e-Learning Best Practices in Management, Design and Development of e-Courses: Standards of Excellence and Creativity, ECONF 2013 2013, pp. 90-96.

Klubal, L., Kostolanyova, K. Forms of the Materials Shared Between a Teacher and a Pupil. In: Sánchez, Inmaculada Arnedillo a Pedro Isaías. Proceedings of the 12th International Conference on Mobile Learning 2016. Vilamoura, Algerve, Portugal: Iadis, s. 4. ISBN 978-989-8533-49-4. (2016)

Kostolanyova, K., Klubal, L. iPad integration in to the current professional practice of teachers in primary and secondary schools. Scientia iuvenis. Nitra: Constantine the Philosopher University in Nitra. s. 450-455. [2014-10-22]. ISBN 978-80-558-0650-1(2014).

Kostolanyova, K., Klubal, L. Practicing in Mathematics Using a Tablet. European Conference on e-Learning Conference Proceedings. ACPI, 2015. s. 714-719. ISBN 978-1-910810-70-5 (2015).

O'Reilly, T. "What is Web 2.0. design patterns and business models for the next generation of software". Radar O'Reilly, 2005. Retrieved 3/12/17 from http://oreilly.com/web2/archive/what-is-web-20.html

Prucha, J., Walterova E., Mares J., Pedagogický slovník. 7., Prague: Portál, ISBN 9788026204039. (2013). 